\section{BESZÁMOLÓ A MABISZ 2017. NOVEMBER 7-I} KONFERENCIÁJÁRÓL

Lencsés Katalin (Magyar Biztositók Szövetsége) katalin.lencses@mabisz.hu

\section{ÖSSZEFOGLALÓ}

A MABISZ 2017 novemberében tartotta VIII. konferenciáját. Az idei rendezvény középpontjában a digitalizáció és az innováció állt. Jelen beszámoló erről az eseményről ad összefoglalót.

\section{SUMMARY}

The Association of Hungarian Insurance Companies (MABISZ) held its 8th conference in November 2017. This year the event focused on digitalization and innovation. This article gives the summary of the conference.

Kulcsszavak: biztosítás, konferencia

Keywords: insurance, conference

JEL: G22

DOI: $10.18530 /$ BK.2017.4.90

http://dx.doi.org/1018530/BK.2017.4.90
A Magyar Biztosítók Szövetsége 2017. november 7-én tartotta VII. konferenciáját a Corinthia Hotel Budapestben. A biztosítási szektor legnagyobb konferenciája ismét kiváló alkalmat jelentett a biztosítók, a velük együttműködő vállalkozások, a szabályozói és felügyeleti döntéshozók képviselői számára a magas szintű szakmai eszmecserére.

A konferenciát a MABISZ fötitkára, Molnos Dániel nyitotta meg azzal, hogy a „felforgató” digitális impulzusokra valamennyi piaci szereplőnek fel kell készülnie. Kérdés, ki hogyan éli meg azokat az átalakulásokat, melyek képét az előadók a konferencia során a továbbiakban felvázolták.

Az első előadó Deutsch Tamás, a Digitális Jólét Programjának miniszterelnöki biztosa volt. A digitalizációról jövő időben szoktunk beszélni, ami az előadó szerint alapvetően téves megközelítés. A digitalizáció a jelen feladata, és a kormány így is gondolkodik a témáról, úgy tekint rá, mint egy sok esélyt teremtő társadalmi átalakításra, amelyet nemcsak a szakemberek érzékelnek, hanem az átlagos emberek is tapasztalni fognak.

A folyamat fontos szereplői az informatikusok, üzletemberek és a szabályozással foglalkozók. Vannak azonban elsők az egyenlők között, mégpedig az ügyfelek, akik igénybe veszik a digitalizáció eredményeként létrejövő szolgáltatásokat. Ma a világ folyamatait, a világgazdaság teljesítményét alapvető módon határozza meg a digitalizáció, ez az egyik legfontosabb hajtóerő. Ami a változások ütemét illeti, az egyre inkább fel fog gyorsulni.

A kormány digitális jólét programjára áttérve az előadótól megtudtuk, hogy az nem egyszerűen a párbeszédre épül, hanem a bizalomra épülő együttműködés logikája. A Digitális Jóléti Program 2.0 verziója pedig újabb 20-25 fejlesztési irányt jelent. Kérdés, melyek azok az irányok, melyek a biztosítókat is érintik? Mindenképpen ezek közé tartoznak a big data fejlesztési irányok, ahol az a feladat, hogy az állam működési körén belül keletkezett adatvagyon gazdasági hasznosítása miképpen oldható meg. Ilyen téma lehet a hazai informatikai kkv-k támogatása, illetve a digitalizációval összefüggő szabályozások kérdése. Utóbbira példaként hangzott el az önvezető autók kérdése, amely újraértelmezheti a felelösségi viszonyokat. Az előadó végül javasolta, hogy készüljön el a magyar biztosítási szakma digitalizációs stratégiája, illetve arra biztatott, hogy mindenki ismerje fel ennek jelentőségét.

Nyugdíjbiztosítások esetében nemcsak a termékek darabszáma nő, hanem az átlagosan befizetett biztosítási díj és a várható tartási idő is.

A második előadó Pandurics Anett, a MABISZ elnöke volt, aki azokkal a kifejezésekkel indított, melyek a digitalizációról elsőként az eszünkbe szoktak jutni: blockchain, önvezető autó, Facebook. A mindennapok azonban nem csak ezekről szólnak. Az innováció folyamatosan velünk van, és nem csak a nagy ötletekről szól. Clayton Christensent idézve bemutatta az innováció három típusát. A piacteremtő innovációk fontosak egy szektor megújításában, 
a leggyakoribbak azonban a fenntartó innovációk, melyek a mindennapokban történnek meg, ezekre egy sor példát adott már a biztosítási szektor. Harmadik típus a hatékonysági innováció, melynek hosszú távon szintén megvan a maga szerepe.

Részben a fentiek eredményeképpen a szektor az elmúlt években növekedni tudott, mely növekedésnek a hajtómotorja elsősorban a nem-élet terület volt, azon belül is húzóág a gépjármü-biztosítás, mely elsőként találkozott élesben a digitalizáció kihívásaival. Ezen a területen a személyes értékesítés jórészt el is tűnt.

Életbiztosításokban a növekedés motorját egyértelműen a nyugdíjbiztosítások jelentik. Ebben is bízott a szakma, amikor 2013-ban ez a termék is megkapta az adókedvezményt: bíztunk abban, hogy elérjük azokat az ügyfeleket, akiket a másik két nyugdíjtermék nem. Örvendetes körülmény, hogy a nyugdíjbiztosítások esetében nemcsak a termékek darabszáma nő, hanem az átlagosan befizetett biztosítási díj és a várható tartási idő is. A kérdés fontosságát mutatja az is, hogy a szakma szektorszinten kommunikálja a nyugdíjbiztosítások fontosságát.

Szó esett még a szektor előtt álló európai szabályozási feladatokról, mint a PRIIPs, IDD, GDPR, IFRS17, melyek alkalmazása jelentős erőforrásokat köt le. Végül a digitalizáció kihívására visszatérve elhangzott, hogy a biztosítási szektor nincsen lemaradva, csak itt mások a folyamatok, mint a banki szektorban: tőlünk azt várják, hogy legyen ügyfélélmény az értékesítés, és legyen kényelmes a kárrendezés, ami más megoldásokat igényel.

Matteo Carbone, a Connected Insurance Observatory alapítója és igazgatója következett, aki azt a kérdést feszegette, hogy a biztosítási szektor innovatív-e. Az általa példaként felhozott brit és német piac alapvetően átalakult az elmúlt években. Néhány biztosító a múltban innovatív volt, és néhány a jövőben is az marad, de ez nem könnyű feladat, és nem is lineáris haladást jelent. Érdemes odafigyelni arra, hogyan használják a cégek az adatokat az értékláncban például az egészségügyi adatok kapcsán, ahol a hangsúly eltolódik a kármenedzsmentről a kármegelőzésre. Vagy arra, hogy miképpen építenek fel egy szolgáltatáscsomagot arra a tényre, hogy valaki kutyát tart, és jutnak el az egyszerű kisállat-biztosításból egy komplex csomaghoz, amely a kutyához kapcsolódó valamennyi igényt kiszolgálja. Ehhez az innovációhoz a megnövekedett adatmennyiségen túlmenően különböző elektronikus eszközök is segítségül szolgálnak. A biztosítási szerződés, az IoT eszközök (dolgok hálózata) és az egyéb szolgáltatások kombinációja új értéket teremthet a biztosítók számára.

Török Péter, a STRATIS partnere azzal a felütéssel kezdte előadását, hogy többnyire rövid távon túl-, hosszú távon pedig alábecsüljük a technológia hatásait. A forradalmi technológiák helyes megítélését hátráltatja, hogy még a technológiai fejlődés korai fázisában tartanak. Megtudhattuk, hogy hosszú távon mire használhatók az IOT eszközök, és arról is szó esett, hogy milyen fejlődési potenciálja van a mesterséges intelligenciának. Elhangzott továbbá, hogy a jövő kommunikációs csatornája a több funkciót tömörítő hordozható technológiáké, ami feladatot jelent a biztosítók számára. Azok, akik ezen az úton elindulnak, ne a meglévő folyamatokat gyömöszöljék bele ebbe az eszközbe, hanem nézzék meg, hogy milyen lehetőséget kínálnak ezek az eszközök az értékesítésben és az ügyfélkezelésben.

\section{A trendszerüen növekvő számok azt jelzik, hogy a biztosítási} piac év végére tíz év elteltével visszatér a válság előtti szintre.

A kávészünetet követően Windisch Lászlónak, az MNB pénzügyi szervezetek felügyeletéért és fogyasztóvédelemért felelős alelnökének előadását hallgathatták meg a konferencia résztvevői. Az előadó az MNB adatszolgáltatásai alapján elemezte a 2017-es évközi piaci adatokat. Kiemelte, hogy a trendszerűen növekvő számok azt jelzik, hogy a biztosítási piac év végére tíz év elteltével visszatér a válság előtti szintre.

A biztosítás penetrációját (díjbevétel/GDP) nézve már nem ilyen rózsás a kép. A biztosítási piac növekedése nem éri el a GDP-növekedést, ezért a penetráció 2,5 százalékos mélypontra csökkent, holott a múltbéli adatok alapján és nemzetközi összehasonlításban is a 3-4 százalékos szint tűnik egészségesnek. Az alelnök elsősorban az életbiztosításban lát teret a növekedésre, a nem-élet ágon kisebbet, az MNB ugyanakkor itt nem a díjszínvonal, sokkal inkább a lefedettség növelésére biztat. Ami a versenyt illeti, a piaci koncentráció eddigi csökkenő trendje megtorpant, sőt megfordulni látszik. $\mathrm{Az}$ új átfogó szabályozások is a mérethatékonyság kérdését helyezik előtérbe, ami szintén a koncentráció irányába nyomja a piacot.

A szabályozási kihívások kapcsán a Szolvencia II-ről továbbra is indokolt beszélni, hiszen idén nyúitották be az első teljes éves adatszolgáltatást a hazai biztosítók. Ennek alapján a szektor tőkefeltöltöttsége (215\%) az uniós átlagnak megfelelő, intézményi szinten a 150 százalékos MNB-elvárás igazodási ponttá vált. Az etikus életbiztosítási csomag sem okozott sokkot - egyes várakozásokkal ellentétben. Az új szerződések darabszámának csökkenését kompenzálja az átlagdíj növekedése, amit az MNB „win-win” helyzetnek tekint. Az MNB azon várakozása is igazolódni látszik, hogy nő a szerződések megmaradási ideje.

A jövő év kihívása a szakmának és az MNB-nek egyaránt az európai IDD és PRIIPs szabályozás. Az MNB támogatja a korábban kialakult együttműködési csatornák használatát a biztosítók és a hatóság között, hogy az európai szabályokat közösen értelmezzük. IDD értékesítési szabályok a felelösebb fogyasztói döntéshozatalt segítik majd, míg a termékellenőrzési és irányítási (POG) szabályok a termékfejlesztés átgondolását kényszerítik ki. Ennek előtérbe kerülése jól mutatja, hogy az európai szabályozás sem elégedett meg csupán a tájékoztatási követelmények szigorításával, hanem a termékoldalra is próbál hatni, ami megerősíti az MNB által az etikus szabályozásban képviselt irányt.

Végül a digitalizációs kihívásokra áttérve megtudhattuk, hogy az MNB folyamatosan figyeli a piaci trendeket, vizsgálja az igényeket, és szeretne a fejlődés élére állni. Mi sem bizonyítja 
ezt jobban, mint a már megszületett felügyeleti ajánlások (online és felhő ajánlás), és folyik a gondolkodás a regulatory sandbox témában is. Ez utóbbit egyre több országban alkalmazzák. Hangsúlyozta ugyanakkor az előadó, hogy az ebben részt vevő cégek versenyelőnyt nem fognak élvezni, a megoldás csak az innovációk kipróbálását teszi lehetővé. Jelenleg a nemzetközi tapasztalatok gyüjtését és a hazai igények feltérképezését végzi az MNB. Az alelnök bejelentette, hogy a bankok után most indítják az igényfelmérési kört a biztosítókkal is.

Kocsis Gergelytől, a Rowanhill Global Kft. ügyvezetőjétől a Blockchainre füzött adatokról hallhattunk előadást. Ennek segítségével - a korábbi technológiákon túlhaladva - adatokat osztanak meg egymással a szereplők, és vannak arra ösztönző rendszerek, hogy a szereplők az erőforrásaikat közös rendelkezésre bocsássák. A technológia legfontosabb előnyei a hagyományos megoldásokhoz képest a költséghatékonyabb rendszerek működése, nincs szükség egy központ fenntartására, minimális a visszaélés lehetősége, továbbá megoldott a jogosultság kezelése és a transzparencia.

Kérdés természetesen, hogyan használható ez a technológia a biztosításban? Példaként az AXA-t említette Kocsis Gergely, ahol paraméteralapú biztosítást vezettek be a repülöjárat két órát meghaladó késésére. Nem kétséges, hogy melyik megközelítés visz elörébb egy céget: sodródva vagy reaktívan és proaktívan reagálni a változásokra - hívta fel a figyelmet az előadó.

Ezt követően Lemák Gábortól, a Finn Tech Group társalapítójától provokatív és gondolkodásra indító felvetéseket hallhattunk. Több előadó részéről is elhangzott, hogy a jövő bizonytalan, de ha ez így van, akkor hogyan lehet stratégiákat építeni? Léteznek ugyan fogódzók, de ezeket nem egyszerű megtalálni. A cégek számítanak a digitálisan érzékeny ügyfelekre, stratégiákat alapoznak rájuk, tömegesen azonban ezek az ügyfelek nem jelennek meg, vagy ha mégis jelentkeznének, akkor igényeik jogszabályi korlátokba ütköznek. Példaként az ügyfél-azonosítás került elő, ami egészen a közelmúltig csak papíron volt lehetséges.

Kérdés tehát, hogy létezik-e jó stratégia, olyan, ami működik, és három év múlva visszamenőleg is igazolódik. Az internetes technológia megteremtette a lehetőséget, hogy az ügyfeleket akár egyenként is meg lehessen szólítani. Hívószavak a platformosodás, ügyfélélmény és adat. Példaként az Uber neve hangzott el, melynek kapcsán az előadó felhívta a figyelmet arra, hogy az Uber semmit nem fejlesztett ki, mindössze azt használja fel a szolgáltatásához, amit más fejlesztett. A kulcsszó itt az applikáció volt. A platformosodásnak ma súlyos technikai alapja van: hogyan lehet a mások által kifejlesztett eszközöket felhasználva, azokra saját szolgáltatást alapozni, vagyis más által létrehozott adatok hasznosításával új értéket létrehozni.

A nap első kerekasztal-beszélgetése cégvezetőkkel zajlott a digitalizáció lehetőségeiről. Résztvevők: Erdős Mihály (Generali), Kisbenedek Péter (Allianz), Sztanó Imre (NN) és Kurtisz Krisztián (UNIQA), moderátor Lambert Gábor. Induló kérdés volt, hogy milyen távra lehet egyáltalán stratégiát készíteni. A válaszok jellemzően azt erősítették, hogy egyre rövidebb távra, három év esetében már 60-70 év fejlődését kellene megbecsülni. Feladat a digitális kultúra építése, ugyanakkor nem szabad elfelejteni, hogy a digitalizáció nem cél, hanem eszköz. A szakmának vissza kell térnie az alapokhoz, vagyis a kárkifizetések fontosságához: a biztosítás lényegéből fakad, hogy annak segítségével az emberek egymáson segítenek jól és kényelmesen. Az sem kérdés, hogy biztosítók hagyományos működését kellene modernizálni viszonylag gyorsan, mert az ügyfél azonnal várja a szolgáltatást, lehetőleg mobil eszközön keresztül.

A mások fejlesztésére alapuló szolgáltatások azzal a veszéllyel járnak, hogy a biztosítók kicserélhető háttérszolgáltatóvá válnak.

A kihívások az egész szervezetet érintik, a megoldások megtalálásában a menedzsment szerepe is megkerülhetetlen. Alapvető változás szükséges például abban a vonatkozásban, hogy egy cég milyen sebességgel hoz döntéseket. További szempont, hogy az informatika kiemelten fontos a menedzsment működésében - aki ezt nem érti, az nem tud jó döntéseket hozni a társaság jövője szempontjából. Feladata továbbá a vezetésnek a kultúraépítés, beleértve a digitális kultúrát is. Az ügyfél-központúság jelszava évek óta mindig elhangzik, ugyanakkor az új technológiákkal nem haladhatunk gyorsabban, mint ahogyan az ügyfelek haladnak. Edukálni kell tehát az ügyfeleket is, mivel minden fejlesztés annyit ér, amennyit használni tudunk belöle.

Az innovációk kapcsán igény, hogy olyan eszközökre menjen el az erőforrás, amelyek már holnap alkalmazhatóak. Probléma ebben a vonatkozásban a magyar piac kis mérete is, mivel a jelentős innovációk nagy piacokon indulnak el. A mások fejlesztésére alapuló szolgáltatások pedig azzal a veszéllyel járnak, hogy a biztosítók kicserélhető háttérszolgáltatóvá válnak. Arra a kérdésre válaszolva, hogy mely terület igényli leginkább az innovációt, elhangzott, hogy a biztosítók az eladásból élnek. Az érték nem abban rejlik, hogy ki fejleszti a legjobb rendszert, hanem hogy az ügyfélkapcsolatban mit tud létrehozni. Van, ahol már lehet bérelni informatikai rendszert, és tranzakciós díjat fizetnek érte - az ilyen példákért már nem is kell elmenni Ázsiáig. A felhőszolgáltatók már tudnak complied módon szolgáltatást nyújtani, az innovatív megoldások nem fizikai szerverekre lesznek telepítve. Végül az is elhangzott, hogy az adat és az értékesítés egyre inkább ugyanaz, a kategóriák egyre inkább összemosódnak.

Az ebédszünetet követően díjátadó következett. A biztosítók már évekkel ezelőtt problémaként azonosították a fiatalok körében szinte teljesen hiányzó biztosítási kultúrát, a fiatal generáció tagjainak nehéz elérhetőségét. A MABISZ kidolgozta a Fiatal Generáció Stratégiáját, melynek keretében első alkalommal került sor az esettanulmány-versenyre egyetemisták körében. A verseny eredményhirdetése a konferencián zajlott. Első helyezett Czigony Claudia és Juhász Blanka lett. A második helyezést Kadocsa Ferenc és Szabó 
Barna érte el, Tamás Zsanett és Vései Viktor pedig a harmadik helyezettnek járó díjat vehette át. A díjazottaknak gratulálunk, a beérkezett versenymegoldásokat továbbgondolásra a biztosítók is megkapták.

Hídvégi Áron, a Századvég igazgatója egy kutatás eredményét ismertette. Itt visszaköszöntek azok az ismeretek, melyeket a biztosítók a mindennapokban is tapasztalhatnak. Az ügyfelek a digitális megoldásokra a legnagyobb nyitottságot a gépjármü- és lakásbiztosítások vonatkozásában mutatják, míg az életbiztosítás esetében igénylik leginkább a személyes kapcsolatot.

A felmérés külön rákérdezett arra, hogy az ügyfelek milyen hajlandóságot mutatnak a mobilapplikáció adatainak megosztására a biztosítókkal. Díjkedvezmény és személyre szabott ajánlat esetén erre van fogadókészség, az ügyfeleket ugyanakkor nem hagyja hidegen az a lehetőség sem, hogy beleegyezésük nélkül mások is hozzáférhetnek ezekhez az adatokhoz.

Kerekes Antal, a PwC partnere az európai GDPR szabályozásra való felkészülésről beszélt. A jövő a még erőteljesebb adatvezérelt működésé, az ügyfélmegismerésé, az egyre több személyhez köthető adaté. A GDPR maga is „készül” erre a jövőre, külön automatizált döntéshozatalra vonatkozó specifikus követelményeket fogalmaz meg.

Fontos ugyanakkor hangsúlyozni, hogy a GDPR alkalmazás nemcsak kötelezettség, hanem lehetőség is. Rövid távú és fenntartandó cél a GDPR követelmények teljesítése. Ezt azonban nem szabad kizárólag jogi és adatvédelmi funkciók által vezérelten véghez vinni. Az „igazi” adatfelhasználó üzleti oldalt is be kell vonni, szövetségessé kell-lehet tenni.

A GDPR által a vállalatok rákényszerülnek a meglévő adatok strukturálására, „tisztább” kezelésére. Mindez lehetőséget teremt a sokszor szétzilált, sok „igazságot” eredményező adatvagyon rendbetételének elindítására is.

A GDPR kapcsán az adatvédelmi szemlélet, kompetencia feltétlen erősítendő, de az üzleti sikerhez a data analytics képességek kifejlesztése elengedhetetlen lesz a jövőben. A GDPR kiváló apropót teremt, hogy számba vegyük az adatokkal foglalkozó, ahhoz értő embereinket is. Végül megemlítésre került, hogy az érettebb piacokon már kipróbált adatvezérelt megoldásokat a hazai környezetben rögtön GDPR compliant módon lehet tesztelni.

\section{A GDPR alkalmazás nemcsak kötelezettség, hanem lehetőség is.}

A délután további két előadásának egyikében Verőczi Gábor, a BM Eszig projektvezetője az e-személyi bevezetésének technikai tudnivalóiról beszélt. Biztosítási szempontból érdekes, hogy az okmány online ellenőrzését teszi lehetővé, a nem érvényes okmányok automatikusan letiltásra kerülnek. Másik fontos tulajdonság, hogy az okmány egyedi azonosítót tud biztosítani. Lex Tan, a MotionsCloud vezetője pedig arról tartott előadást, miért szükségszerű, hogy a biztosítótársaságok együttműködjenek a fintech cégekkel.
A konferencia utolsó szakmai programja a HR vezetők kerekasztal-beszélgetése volt. Résztvevők: Bába Szabó Magda (Generali), Karászi Gyöngyi (Aegon), Veres Rita (AON HEWITT), a beszélgetést Frankó-Csuba Dea (Spark Institute) moderálta.

A középpontban itt is a jövő kihívásai álltak: milyen problémákkal szembesülnek a biztosítók, illetve hogyan változnak a munkavállalók elvárásai. A biztosítók számára mindenképpen kihívás lesz, hogy új mentalitással kell megbirkózniuk: korábban a lojális munkaerőhöz voltak szokva, a következő generációk azonban már elkezdték a piacot körbejárni. Ez az új típusú munkaerő a fejlődés lehetőségét keresi a karrierben és a személyes kompetenciákban egyaránt. Ez kiegészül a siker iránt igénnyel, ami a digitális világban gyorsan változik. Az új generáció már kevésbé gondolkodik a hierarchikus karrierépítésben, sokkal fontosabb számára, hogy személyes portfóliója minél színesebb és gazdagabb legyen.

A HR vezetők a következő öt évre nem várják, hogy a mesterséges intelligencia tömegesen szüntetné meg a munkahelyeket, sokkal inkább az erősödő hiányról fog szólni ez az időszak. Léteznek ugyanakkor olyan szakmák, ahol az emberközi kapcsolat még jobban fel fog értékelődni, éppen ezért ezt a vonalat is szükséges erősíteni.

A jövő minden valószínűséggel a kis teamekre építő, hálózatos, mozgékony szervezetekről fog szólni. Ez is kihívás, mivel idáig a hierarchikus rendben való eligazodást vártuk el a munkavállalóktól, most pedig azt kérjük tőlük, hogy az állandó változáshoz való alkalmazkodást tanulják meg, ennek kapcsán felértékelődik az érzelmi intelligencia képessége.

Végül nagyon fontos szempontot vitattak meg a beszélgetés résztvevői. Mindenki a fiatalokról beszél, miközben egy idősödő társadalomban élünk. Nem kerülhető meg a szervezeti kultúrára kérdése: hogy az idősebb munkatársak mennyiben befogadók az új technológiákra, hogyan lehet bemutatni a számukra, hogy az új technológiák jók és hasznosak, illetve hogyan lehet kiválasztani a munkatársak közül az erre fogékonyakat. Ebben nagy segítséget jelentenek az olyan eszközök, melyeket egyszerre használunk a munkához és a magánélethez. Amennyiben ilyen eszközöket adunk a munkatársak kezébe, azzal játékossá tesszük az új ismeretek elsajátítását.

Az eseményt a MABISZ főtitkára, Molnos Dániel zárta, kifejezve reményét, hogy a résztvevők számára tartalmas és gazdag programot kínált a nap, és egyben rögzítette annak fontosságát, hogy a biztosítók, a döntéshozók, illetve a felügyeleti szervek képviselői a jövőben is folytatják a konstruktív együtt gondolkodást a hazai biztosítási piac és az ügyfelek érdekében.

Az érdeklődők az előadások anyagait megtalálják a MABISZ konferencia honlapján: http://mabiszkonfereñia.hu/ 